\title{
ARCHITECTURE AND URBANISM IN ROMANIA, 1944-1960: CONSTRAINT AND EXPERIMENT - A SYNOPSIS
}

\author{
Paul MUTICĂ \\ Technical University, Cluj-Napoca, Faculty of Architecture and Urban Planning, ROMANIA \\ paul.mutica@arch.utcluj.ro
}

Arhitectură și urbanism în România, 1944-1960: constrângere și experiment [Architecture and Urbanism in Romania, 1944-1960: Constraint and Experiment] /Doctoral Thesis, Irina TULBURE; Simetria, Bucharest, 2016, 295 p., ISBN 978-973-1872-41-4

DOI: http://doi.org/10.23740/TID120197

\section{INTRODUCTION}

The period immediately following the end of WWII and the Soviet occupation of Eastern Europe is marked by the enforced transition from a democratic to a totalitarian regime. Architecture became one of the main forms of political expression and propaganda for the new regime that boasted a new, more egalitarian system but in fact was responsible for many persecutions of political dissidents. The political doctrine relied heavily on forced industrialization following the

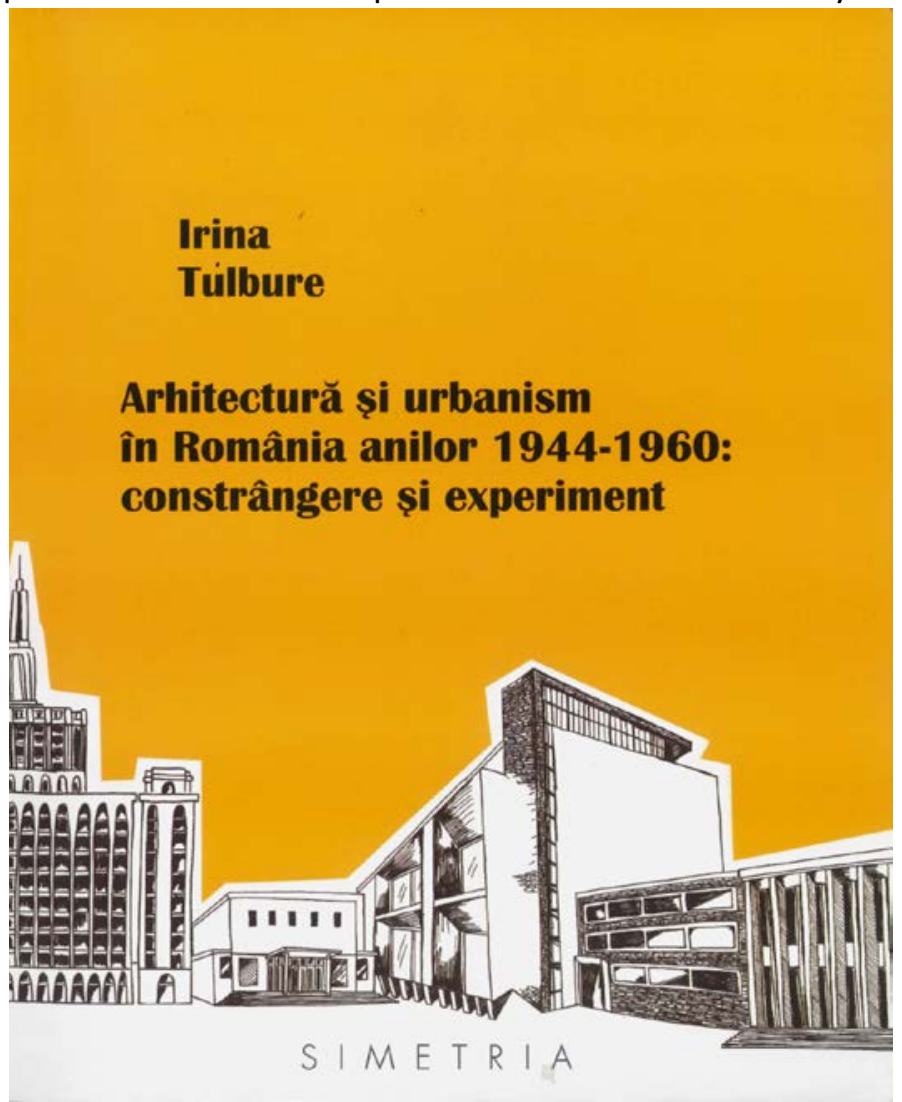

Soviet example (Tismăneanu, 2005, pp. 146-147) and encouraged resettlements of the rural population to the cities through a planned economy system that also gave urban planners a lot of power and responsibility (Jurov, 1979, p. 58). The ambitious plans required the mass construction of worker quarters and habitation units as well as many new neighbourhood amenities, most commonly for the growing working class. The society was changing, and architecture and urbanism needed to keep the pace for everybody to see the communist government was able to live up to the expectations. It is in this very particular context that architecture started to follow less the avantgarde tendencies of modernism and more the politically dictated image of the new socialist city. 
Architecture and Urbanism in Romania, 1944-1960: Constraint and Experiment deals particularly with this 16-year transition period from a relatively young, but well-established modernist practice in Romanian architecture before 1944, to a more retrograde and politically imbued discourse known as Socialist Realism and later on labelled simply as Stalinism. Yet the Stalinist label is pejorative and Irina Tulbure usually avoids it and manages to treat the period with what Ana Maria Zahariade (2011) calls a "scandalous objectivity", shattering clichés and revealing to us a far more complex practice, oscillating largely between the liberal free form of interwar years and the more rigid Soviet imposed model on one hand, but also between the anti-contextual modernism and the national traditional revival, on the other hand (Zahariade, 2011, p. 48). In fact, the architecture might have varied greatly from just a few years before and there were very strict principles to obey, but the architects were more or less the same people, and this sometimes transpired in the objects they created.

Following Stalin's death, the foreign Soviet influence was less prominent, and this led to the replacement of international Socialist Realism with a more national type of approach. The nationalistic communist branch of the party in Romania seemed to favour the blending of modernist ideals and traditional, even folk motives in architecture, replacing the former displays of architecture as too monumental, cold and impersonal after the end of this 16-year transition period.

Yet some of the examples of the period remain inhabited to this day despite them being standard and premade projects only vaguely adapted to local context. Seen as a monument to a very controversial period in history when external political influence managed to erase in just a few years the free speech that enthusiastically marked the Spring of Nations, they tend to be disregarded for what they stood for rather than for their intrinsic qualities. It is in this particular field that Irina Tulbure's study manages to do justice to these architectural objects, more than half a century after their completion.

\section{PERSPECTIVES}

The study focuses on three main perspectives which the author calls reading grids. The first encompasses the socialist project in its whole, from political discourse to social context and includes the written accounts in several publications of the time, mostly severely censored. The second perspective comes from analysing the very mechanisms by which these projects were implemented, including here the political reformation of architects and engineers in particular and of the society in general. Finally, the third point of view focuses on the continuity of the architects and the professional nucleus in general as individuals who were schooled in the interwar years and remained mostly true to the liberal ideals of that time. They sometimes attempted to resist, though faintly, to the exterior imposed strict model of Socialist Realism, sometimes with a certain degree of success.

The book is structured into three unequal parts. The first, entitled Premises, deals with the context in which post-war architecture came to be in the former Communist bloc, from building the political Soviet empire in the 1920's and 1930's to the manifest of Socialist Realism and several examples throughout Eastern Europe following WWII. After 1952 and Stalin's death, the Soviet iron fist relented to a certain degree and allowed for national variations to their strict model and the last chapter of this part deals with local legislation in Romanian context. 
The second part is the most extended and deals with the various forms of architecture in Romania during these 16 years, further divided into four 4-year sub-periods. It is symbolically entitled And form follows... politics. It stretches from understanding architecture as a political discourse to many examples of new city building efforts and finally to several well-chosen architectural examples. In the words of Nae Lascu, the chapter is important for it allows us to truly grasp the way in which Soviet architecture was imported in Romania during the Socialist Realism movement. For the examples vary greatly depending on period and context, whether they are from Bucharest (including Casa Scânteii which directly alludes to the 7 high-rise buildings of Moscow), Hunedoara, Galați or Valea Jiului. In fact, this huge variation in shapes and sizes further suggests that the architectural import was more doctrinarian than formal in its realization.

Finally, the third part - From social policies to socialistic politics, is meant to be a focus on habitation buildings, particularly the social habitation unit - the main programme of the era (which however started a few decades ago), with worker housing and neighbourhood amenities at its centre point. The regime took pride in differentiating itself from its capitalist counterparts by emphasizing the need for public space and cultural revenues rather than commercial and office buildings that form the backbone of Western European and American cities. New venues such as the open air theatre, the worker's club and cinema, the house of culture or the commercial-cultural complex are but a few of these programmes that heavily underlined the importance of full public access and "mass culturalization" and were continuously used for propaganda purposes as well.

The projects themselves needed to be superlative at first, following the Muscovite example of which Lomonosov University is probably the most renown. Casa Scânteii in Romania is similar to Ukraine Hotel in Kiev, the Academy of Sciences in Riga, the Russian Federation Embassy in Berlin, to Moscow Hotel in Prague or to the Palace of Culture in Warsaw. Later on, after 1956, one of the main detractors of Socialist Realism will invoke the utter functional insincerity of most of these buildings who look alike, regardless of the programme they house inside.

The first years of the period marked by absurd monumentality and flamboyant decoration were then replaced slowly by more down to earth developments that featured less ornaments and a homier atmosphere. Yet the preference for symmetry and rigidity was still in conflict with the modernist precepts that most of these architects were taught and preferred just a few years before. Only after the 1950s were over could this imposed perspective be finally challenged by the architects and engineers in pursuit of a national inspired and less rigid aesthetic.

Also, as a parallel to the presentation of architectural objects themselves, we are given a backstage ticket to some of the discourses that were formulated in the era. The texts written during the period vary greatly between pompous and demiurgical statements extracted from official documents and honest and objective descriptions of certain phenomena and processes (Pascariu, 2011, p. 112). We even see how one critic or another changes the nuances in their writings from neutral and objective analysis to subservient and reprovable praise as commanded by the party in a matter of just a few years. Soon, the censorship is so harsh that any critique which tries to leave out inflammatory political parallels from their architectural speech is brutally admonished for not contributing to the development of modern socialist society. Again, we see this tendency inflate and then slowly decrease following the death of generalissimo Stalin and his infamous presence. 


\section{CONCLUSIONS}

A well deservedly acclaimed doctoral thesis, very meticulous and thorough, Architecture and Urbanism in Romania, 1944-1960: Constraint and Experiment manages to shed new light on the corpus of buildings that marked the turmoil of late 40's and 50's Romania. Whether we like it or not, several of these buildings still impact greatly the landscapes of our cities and we would be better of adopting them and sometimes reconverting them to more current facilities than to act as if they never existed solely because they represent a memento of a sad turn of events in our history. It seems youngsters who never lived during Communism are more prone to do so and more curious about these relics than those who lived during their commissioning which is, in a way, an optimistic outcome and a fact to consider.

Irina Tulbure's style of writing is particularly compelling as she takes us on a journey on several well differentiated fronts, from the study of archives and political minutiae to browsing through publications or public interviews of the time and from the urban context to the very minute details of an entrance or balcony. Overall, the curiosity and enthusiasm of the author are very contagious and her patience and attention to details demonstrate beyond doubt that there is no simple black and white when it comes to analysing the remnants of Socialist Realism in architecture but far more nuances in between.

\section{REFERENCES}

JUROV, C. (1979). Centre civice. Contribuții la definirea și conceperea unor tipuri de centre civice multifuncționale pentru viitoarele orașe mici [Civic Centres. Contributions in Defining and Conceiving Certain Types of Multifunctional Civic Centres for Future Small Cities]. București: Editura Tehnică.

PASCARIU, G. (2010-2011). Planificare teritorială în anii comunismului [Territorial Planning during Communism]. Urbanismul Secolului XX, 7-8, 112-116.

TISMĂNEANU, V. (2005). Stalinism pentru eternitate [Stalinism for Eternity]. Iași: Polirom.

TULBURE, I. (2016). Arhitectură și urbanism în România, 1944-1960: constrângere și experiment [Architecture and Urbanism in Romania, 1944-1960: Constraint and Experiment]. București: Simetria.

ZAHARIADE, A.M. (2011). Arhitectura în proiectul comunist. România 1944-1989 [Architecture in the Communist Project. Romania, 1944-1989]. București: Simetria. 